Please do not remove this page

RMIT

UNIVERSITY

\title{
Retail centres: it's time to make them convenient
}

Reimers, Vaughan; Clulow, Val

https://researchrepository.rmit.edu.au/esploro/outputs/9921859340701341/filesAndLinks?institution=61RMIT_INST\&index=null

Reimers, V., \& Clulow, V. (2009). Retail centres: it's time to make them convenient. International Journal of Retail \& Distribution Management: Incorporating Retail Insights, 37(7), 541-562.

https://doi.org/10.1108/09590550910964594

Document Version: Accepted Manuscript

Published Version: https://doi.org/10.1108/09590550910964594

Repository homepage: https://researchrepository.rmit.edu.au

(c) Emerald Group Publishing Limited

Downloaded On 2023/04/26 18:18:41 +1000

Please do not remove this page 
Thank you for downloading this document from the RMIT Research Repository.

The RMIT Research Repository is an open access database showcasing the research outputs of RMIT University researchers.

RMIT Research Repository: http://researchbank.rmit.edu.au/

\section{Citation:}

Reimers, V and Clulow, V 2009, 'Retail centres: it's time to make them convenient', International Journal of Retail and Distribution Management: Incorporating Retail Insights, vol. 37 , no. 7 , pp. 541-562.

See this record in the RMIT Research Repository at:

http://researchbank.rmit.edu.au/view/rmit:22795

Version: Accepted Manuscript

Copyright Statement: (c) Emerald Group Publishing Limited

Link to Published Version:

http://dx.doi.org/10.1108/09590550910964594 


\title{
RETAIL CENTRES: IT'S TIME TO MAKE THEM CONVENIENT
}

\author{
Abstract \\ Purpose - This paper explores the influence of time convenience on shopping behavior \\ in the light of a time scarcity phenomenon that is reported to have reached epidemic \\ proportions in many markets. \\ Design/methodologylapproach - The study begins with a survey of consumer \\ households, examining the importance shoppers assign to time convenience. This is \\ followed by a supply-side comparison of malls and shopping strips against the attributes \\ of time convenience. \\ Findings - The results indicate that time convenience has a salient influence on \\ consumers' patronage behaviour, and that malls and strips differ in their provision of this \\ key attribute. \\ Practical implications - Retail planners must give serious thought to creating retail \\ environments that allow shoppers to 'buy' time. Providing time convenience via one-stop \\ shopping, extended trading hours, proximity to home or work and enclosure offers one \\ such strategy for the shopping mall and shopping strip. \\ Originality/value - The focus on convenience provides practitioners with a strategic \\ alternative to hedonic strategies. It is also one of the first studies to investigate retail \\ centre patronage from both a demand- and supply-side perspective. \\ Key words: shopping, patronage, retail centres, malls, convenience, time scarcity. \\ Paper type: Research paper
}

\section{Introduction}

Time scarcity is reported to have reached epidemic proportions. Studies reveal that Americans work longer hours today than they did 50 years ago and that approximately $60 \%$ report feelings of time scarcity and the pressure to work too much (New American Dream, 2003). This problem is not limited to the U.S. A Canadian study found that nearly half of all Canadians feel that due to a lack of time they are unable to handle their daily activities effectively (Fast and Frederick, 1998). Studies also report the same trend in Australia, Europe and Asia (Hamermesh and Lee, 2007).

There are several reasons behind time scarcity. The first stems from the notion that it is more prevalent in higher-income households. A key source of time scarcity in consumeroriented societies is taking on additional work in order to improve one's material lifestyle (Kaufman-Scarborough and Lindquist, 2003). Moreover, it is not simply a matter of individuals working longer hours; household units are also spending more time at work. As such, the prevalence of dual-income households serves as another major cause of time scarcity (Alreck and Settle, 2002). In today's society, most affluent households derive their income from paid employment. The association of high incomes and time scarcity is due to the tendency for those with high levels of human capital to live together, and for both partners to work longer hours (Sullivan and Gershuny, 2004).

There is also the view that feelings of time scarcity are caused by perception rather than reality. Such a view stems from the fact that with actual leisure time having increased for many consumers, feelings of time-pressure stem from a lack of effective timemanagement skills rather than a lack of time itself. Hence, the problem of time scarcity is not simply limited to those that work long hours (Kaufman-Scarborough and Lindquist, 2003). 
Technology serves as another explanation behind increasing time scarcity. In theory, technological acceleration should have freed up more time for leisure, thereby slowing the pace of life. However in reality, it has simply increased it. Due to technological innovations such as mobile phones, pagers, BlackBerry devices, laptop computers and the Internet, the division between home and work has blurred, creating the feeling of being 'on call' all the time (Wajcman, 2008).

Given that time has been described as the currency of the contemporary consumer (Kaufman and Lane, 1994), the link between time scarcity and shopping is particularly pertinent. Moreover, it is women - the predominant shopping segment (Mitchell and Walsh, 2004) - that are most likely to experience time scarcity. While there are two contrasting views as to the relative amount of leisure time available to women, the end result is still the same. The first view holds that women enjoy the same amount of leisure time as men, but are more likely to feel time stress because their leisure time is often interrupted by the presence of children, meaning it is less restorative (Wajcman, 2008). The alternative view is that women are more prone to time stress because they simply enjoy less leisure time than men (Fast and Frederick, 1998).

Shoppers are not only limited by the time available to them but also its flexibility. In a study of how consumers allocate time to the various activities vying to be a part of their daily schedule, they were found to be least flexible in the time they can allocate to shopping (Joh, Arentze and Timmermans, 2006). Daily schedules influence shopping behaviour by limiting the time available to shop. Shopping trips are not an isolated event, but rather are planned and scheduled as part of a routine. As such, patronage behaviour is not only influenced by retail attributes, but time constraints as well (Arentze and Timmermans, 2005).

A review of literature thus far has revealed that there is a significant group of people with money to spend, but without the equivalent leisure time in which to spend it. This means that many western economies are faced with the question of how to get those that earn the most income but work the longest hours and have the least leisure time, to maintain or increase their consumption expenditure. Sullivan and Gershuny (2004) propose that the only way to bridge the gap between high incomes and limited shopping time is inconspicuous consumption. Such behaviour refers to the purchase of leisure goods that are stored away due to lack of time but with the intention to use them at some imagined future date when there will be time. As such, it serves as a form of virtual leisure and is based on the notion that when those with the most money cannot find the time to spend it, virtual leisure must replace real leisure.

There is an alternative view that when confronted with time pressure, consumers seek to 'buy time' by utilising methods that reduce shopping time. In this context, the Internet and catalogue serve as two of the more widely recognised time-buying strategies. However they offer a less-than-perfect solution because while they reduce the time taken to place an order, it is counter-balanced by the delay consumers' face in taking possession of the goods. This may explain why catalogue and Internet shopping are highly regarded as potential time-saving strategies, but rank poorly when compared with actual time-saving practices. Instead, consumers are more likely to turn to traditional store-based strategies such as visiting the nearest facility or shopping at facilities offering extended trading hours (Alreck and Settle, 2002). 
Moreover, the appeal of time-saving strategies in not just limited to those with a convenience-orientation. Time stress has also left many hedonic consumers with little time for leisurely shopping (Alreck and Settle, 2002). Kim and Kim (2008) found that time scarcity compromises the hedonic pleasure derived from browsing. They therefore warn that hedonic value should not come at the expense of time-saving strategies, and malls that ignore this, risk losing recreational shoppers to more convenient retail formats such as neighbourhood centres, power centres and strip centres.

In response to increasing time scarcity, many consumers have begun performing more than one activity at a time (referred to as polychronic behaviour). In a shopping context, this translates into multi-purpose shopping and one-stop shopping (KaufmanScarborough and Lindquist, 2003) and accounts for the success of retail facilities such as the supercentre (Carpenter, 2008). Trends such as these have been interpreted as indicating that to succeed in today's time scarce environment, retail facilities must offer value for time in the same way they strive to offer value for money (Acland, 2000).

The purpose of this study is to measure the importance consumers assign to time convenience and to compare shopping malls and strips in its provision. The rest of this paper is structured as follows: first a review of literature provides the background to the research questions that serve as the focus of this study. The methodology is then described, followed by the presentation of results, and conclusions thereafter.

\section{Review of literature}

The four attributes of a retail centre that influence the temporal convenience it offers are one-stop shopping, trading hours, enclosure and proximity to home/work (Reimers and Clulow, 2008A). The term one-stop shopping implies that all but the most esoteric of shopping needs can be satisfied in the one centre, all at the one time (Kaufman, 1996). Because consumers are increasingly undertaking multi-purpose shopping trips (Arentze, Oppewal and Timmermans, 2005), they are likely to favour centres that offer one-stop shopping (Kaufman, 1996). The declining number of shopping trips in combination with the increased number of stores visited per trip is perceived as testifying to this notion (Liebmann, 2000). Yet in spite of this, there have been few empirical studies on the importance of one-stop shopping. This is surprising given that retail studies have consistently identified the wider attribute of merchandise selection as a salient determinant of patronage behaviour (Frasquet, Gil and Molla, 2001; Anselmsson, 2006).

Extended trading hours: The demand for extended trading hours derives from the emergence of a 24-hour society. The increased fragmentation of working hours has changed consumer perceptions of what people should do and when. In such a climate, competing on the basis of time becomes all important (Richbell and Kite, 2007). In the words of Mason, Mayer and Wilkinson (1993, p 620), "Logically if the marketing concept has meaning, consumers should be able to shop when they choose. This means retailers have a responsibility to be open when customers want to shop". In fact, one of the key services retailers provide is time utility: making products available at times when they are needed (Assael, Reed and Patton, 1995). Extended trading hours are now considered by retailers to be a key part of their value proposition and a means of countering the "shop anytime" convenience offered by direct-marketers (Schultz, 1997).

It is therefore not surprising that retail studies have found trading hours to have a significant influence over retail centre patronage. While Kim and Kang (1997) identified seven factors influencing the patronage of malls, strip malls, power centres and factory 
outlets, only lower prices, easy product return and convenience - a factor comprising trading hours - were regarded as important by patrons of all four retail formats. Yavas (2003) found trading hours to be among the more salient influences over patronage, ranking ahead of such hedonic attributes as the provision of entertainment facilities, a place to spend time, an "in" place, and special events and promotions. And in a study of eight factors impacting upon the patronage of a mall, Anselmsson (2006) found that convenience (comprising trading hours) served as the third most important influence over satisfaction and the fifth largest influence over mall-visit frequency. Hence, trading hours appear to exert a salient influence over patronage behaviour. However there are doubts as to whether they serve as an important attribute for all shoppers. This is an issue that will be addressed by the second research question.

Enclosure: It has been suggested that climate influences consumer behaviour at least as much as age, income or any other demographic characteristic (Schwartz, 1992). One view holds that in order to ensure the comfort necessary to attract consumers, malls must provide climate control via enclosure (Muto, 1994). As excursions to shopping strips are often shortened or cancelled during extreme weather (Stoltman, Morgan and Anglin, 1999), enclosure is regarded as a prerequisite for success in markets subject to climatic extremes. Enclosure not only offers shoppers protection from the elements, but the noise traffic and odours that often characterise the shopping strip. Moreover, by creating a sheltered, pleasant environment, it can encourage shoppers to relax and enjoy the shopping experience itself (Csaba and Askegaard, 1999).

However these potential benefits have not always translated into positive attitudes towards enclosed malls. Because consumers perceive entertainment value in being outside in fine weather (Pacelle, 1996), many malls have been de-roofed in order to create a town-centre atmosphere where people can socialise (Doubilet, 1999). And for nostalgic reasons, many older consumers would like today's malls to look like yesterday's shopping strips (Balazs, 1995). The move back towards open-air structures also emerged as a result of the uniformity associated with enclosed malls, and the desire for unique shopping places that reflect the characteristics of the locality. For all these reasons, many shoppers now prefer more natural environments where there is daylight and a feeling of contact with the outside world (Coleman, 2006).

Somewhat surprisingly given the unresolved nature of this debate, there have been relatively few studies examining the importance of enclosure. Dennis, Newman and Marsland (2005) studied the attributes that influence retail spending and found enclosure to be one of the five most important determinants. However, more typical of the confused nature of the debate, Kim, Christiansen, Feinberg and Choi (2005) found that despite the fact that a majority of respondents indicated that the weather affected their patronage behaviour, 76\% still indicated they prefer an outdoor shopping area.

Proximity: At least in theory, the closer a retail centre is to where a consumer lives or works the more convenient it should be for them to shop there. However, the vast body of out-shopping research empirically shows that consumers will not always visit their closest facility. In the process of seeking to maximise value, consumers may visit a more distant centre if it offers better entertainment or convenience opportunities. In the context of the latter, out-of-town malls seek to compensate for their outlying location by offering consumers other forms of convenience such as one-stop shopping and easier access and parking. This may explain why when Eppli and Shilling (1997) measured the effect of proximity on patronage behaviour they found it to have surprisingly little impact. 
However, other studies have revealed that proximity does exert a salient influence over patronage behavior. In a study of the impact of daily schedules on shopping behaviour, Arentze and Timmermans (2005) found that the busier the schedule, the greater the likelihood the nearest centre would be chosen. Anselmsson (2006) found that while the proximity of a mall had little impact on customer satisfaction, it was the major determinant of visit frequency. Moreover, such is its importance, that satisfaction was only relevant as a determinant of patronage when the mall was located within proximity. As such, location served as a more important determinant of mall-visit frequency than mall satisfaction.

A review of the literature reveals that in spite of the potential benefits associated with each of the four attributes, doubt still exists as to how significant an influence time convenience has over consumers' patronage behaviour. This issue leads to the first research question.

Research question 1: How important is time convenience in determining consumers' retail centre preference?

There is a growing perception that hedonic shopping strategies serve as the best option for retail centres to preserve or grow their market share (Moss, 2007). In such a context, convenience and its potential to save time and effort, is often assigned a lower priority. This is based on the view that consumers are prepared to expend time and effort on shopping because they enjoy it. Subsequently, consumers favouring convenience have often been regarded as a smaller subset of a much larger market.

Such a notion appears to hold true in relation to time convenience. For example, in spite of the potential benefits offered by extended trading hours, there is evidence to suggest it does not hold universal appeal. This is particularly true in the case of older shoppers. Their life circumstances often allow them to shop during traditional business hours on weekdays (Balazs, 1994). As such, whereas one study found that almost $90 \%$ of those aged under 29 would shop in the evening, 85\% of older shoppers indicated they would not (Kaufman and Lane, 1994). Similarly, research suggests that the importance of trading hours may be mediated by gender, because women are less likely to shop during the evening (Geiger, 2007). Moreover, with the propensity for consumers to patronise their nearest centre varying according to age, gender and income (Handy and Clifton, 2001; Fitch, 2004), there are also doubts as to the universal appeal of proximity. This leads to the second research question.

Research question \#2: Is the importance of time convenience limited to a smaller subset of the population?

Research on malls and strips has typically treated them as two distinct research areas (Anselmsson, 2006). This is a perplexing oversight given that the mall's ability to gain market share at the expense of the shopping strip is regarded as a major trend in retailing (Gorter, Nijkamp and Klamer, 2003; Teller and Reutterer, 2008). With convenience serving as the guiding criterion in its formative years, it naturally follows that the early success of the mall would be attributed to its superior shopping convenience (Gruen and Smith, 1960). However the more recent literature appears to have overlooked this, attributing the success of the mall to a variety of other factors instead (Farrell, 2003; Moss, 2007). Subsequently, strategies for preserving or expanding the 
market share of malls and shopping strips often focus on improving their hedonic value (e.g. Beyard, Braun, McLaughlin, Phillips and Rubin, 2001; Moss, 2007).

However the same general argument that supports this stance can also be used to refute it. For the reasons discussed earlier, consumers' desire for time convenience can also be expected to influence their preference when choosing between malls and shopping strips. Convenience has been attributed with shaping the fortunes of various retail formats (Kim et al, 2005; Kim, Sullivan and Forney, 2007), and malls and strips are likely to be no exception. Houston and Nevin (1980) compared consumer attitudes toward four malls and a shopping strip and identified three significant factors: merchandise, convenience and positioning. While the strip under-performed on all factors, it was particularly deficient in terms of convenience. McGoldrick and Thompson (1992) compared consumer attitudes towards malls and strips, and found that many of the reasons why consumers preferred malls stemmed from issues relating to convenience. In a more recent study of consumer preference between malls and shopping strips, Reimers and Clulow (2008B) found that consumers preferred and visited most frequently, the retail format they considered most convenient.

In measuring the importance of convenience it is therefore necessary to utilise two additional measures. Consumers have been found to use different criteria to assess shopping malls and shopping strips (Leo and Philippe, 2002), with the criteria used for malls having more of a convenience orientation (Hackett and Foxall, 1994). Hence while consumers may regard time convenience as important, the differing decision criteria they use for the two retail formats, means it may not impact upon their choice between malls and strips. Hence, the first of these additional measures is designed to determine the influence of time convenience over consumers' preference between the two retail formats.

Research question 3: How does time convenience influence retail centre preference?

The second measure is a deductive one designed to gain insight into the importance of convenience by establishing whether any differences that exist in the provision of time convenience could account for the varying fortunes of the two retail formats. While enclosure serves as an obvious distinction between malls and shopping strips, one-stop shopping and proximity also serve as potentially significant differentiators.

Given that from its very inception the mall was deliberately designed to provide for onestop shopping (Lewison, 1997), it is surprising that studies comparing malls and strips with any such focus are few in number and are often dated. Houston and Nevin (1980) compared malls and shopping strips and found that merchandise was one of three key factors influencing perception and patronage for both. Similarly, Hackett and Foxall (1994) compared consumer values in a shopping strip versus those in a mall and found that merchandise served as a salient influence for both. However, no study has yet to directly compare the two retail formats in terms of one-stop shopping.

The significance of proximity as a potential source of differentiation stems from the notion that the regional mall's ability to counter the inconvenience of an outlying location may have been compromised by its shift in focus from convenience to recreation. This has led to distant car parks and excessive walking distances between stores, which when combined with an outlying location, may have rendered the regional mall too inconvenient for many consumers. The importance of proximity to the mall is further 
enhanced by the fact that mall homogeneity has increased the likelihood that consumers will shop at their nearest centre (Ibrahim and $\mathrm{Ng}, 2002$ ). Hence, while one-stop shopping, enclosure and extended trading hours serve as potential sources of competitive advantage for the mall, the same may hold true for proximity and the shopping strip. This leads to the fourth research question.

Research question 4: How do malls and shopping strips compare in the provision of time convenience?

\section{Method}

Multiple approaches were used to address the research questions. In order to address the first three questions relating to the influence of time convenience over patronage behaviour, the first approach focused on consumer attitudes. This phase of the study is referred to as the demand-side analysis. The second approach involved comparing malls and shopping strips against the attributes of time convenience and is referred to as the supply-side analysis.

\section{Demand-side method}

Questionnaire design

A self-administered survey served as the measurement instrument for the demand-side analysis. Respondents were asked to indicate on a 7-point scale (1=not important, $7=$ extremely important) the importance of various attributes in determining their retail centre preference. While this list comprised mainly convenience attributes, some hedonic attributes were also included in order to provide insight into the relative importance of convenience. Data was also collected on age, sex, education and location in order to develop a respondent profile.

Location was included because Melbourne's four geographic zones offer somewhat distinct retail scenarios, and therefore serve as a potential influence on attitude. The northeast zone contains one shopping strip and seven shopping malls, the southwest zone contains seven shopping strips and one shopping mall, the northwest zone contains six shopping strips and three shopping malls and the southeast zone contains five shopping strips and six shopping malls. This provided a scenario of two zones dominated by shopping strips (the southwest and northwest zones), one dominated by shopping malls (northeast), and another offering a more balanced retail provision between malls and shopping strips (southeast).

\section{Attitude context}

Because attitudes are context specific (Quee, 1999), they must be measured in a specific shopping context. In retail studies the most commonly used context is the purchase of shopping goods. There is some justification for this because measuring attitudes towards convenience in the context of lower-order goods is somewhat redundant given that it is already acknowledged as the primary criterion behind their purchase (Assael, 1992). By the same token however, the purchase of higher-order goods such as clothing is often linked with a recreational orientation (Dholakia, 1999), creating a potential bias that may understate the importance of convenience. Moreover, because many shopping trips are multi-purpose (Leszczyc, Sinha and Sahgal, 2004), using the purchase of a single product as the shopping context could be considered contentious. By using multi-purpose shopping as the context for this study, it not only provides an alternative to two shopping contexts that may either understate or 
exaggerate the importance of convenience, it also incorporates a key form of shopping behaviour.

Subjects

Mail questionnaires were sent to a random sample of 1600 households within the greater Melbourne area and directed to the primary adult shopper in each household. Of these 151 were undeliverable and 12 were ineligible due to factors such as missing data, late return and failure to meet selection criteria (e.g. adult shopper). In all, 541 useable questionnaires were received, providing a response rate of $38 \%$. Analysis of the respondent profile indicated the potential for some non-response bias, with 18-40 year olds being slightly under-represented in the final analysis. At first glance the gender profile also suggested that males were also under-represented, making up just $37 \%$ of the sample. However this is to be expected given that the questionnaires were directed to the primary adult shopper and that shopping is an activity still regarded by many as a predominantly female role (Mitchell and Walsh, 2004).

\section{Evaluating indicators}

The 20 items used to measure consumer attitudes towards the various retail centre attributes were subjected to principal components analysis using SPSS. Both the KaiserMeyer-Oklin test $(.80)$ and Bartlett's Test of Sphericity $(p<.001)$ indicated the data were suitable for factor analysis. Eigenvalues were then used to determine the number of factors to rotate. Principal components analysis revealed the presence of six components. Consequently, six factors were rotated using a Varimax rotation procedure. For the purpose of interpretation, each factor comprised variables that loaded .40 or higher on that factor (Malhotra, Hall, Shaw and Crisp, 2002). The six-factor solution explained a total of $65.1 \%$ of the variance (table 1 ).

Table 1: Rotated component matrix

\begin{tabular}{|l|l|l|l|l|l|l|}
\hline Item & Con.1 & Con.2 & Con.3 & Con.4 & Con.5 & Con.6 \\
\hline The centre has a compact design & .805 & & & & & \\
\hline Shops are separated from businesses & .787 & & & & & \\
\hline It does not exceed 400m in length & .774 & & & & & \\
\hline Similar stores are located together & .704 & & & & & \\
\hline It has all the stores for one-stop shopping & & .783 & & & & \\
\hline It's close to where you live or work & & .730 & & & & \\
\hline It's open weekday evenings and weekends & & .647 & & & & \\
\hline It provides protection from the weather & & .600 & & & & \\
\hline You can park close to desired stores & & & .751 & & & \\
\hline It has the type of parking you prefer & & & .694 & & & \\
\hline There are plenty of places to park & & & .637 & & & \\
\hline It uses alternatives to traffic lights & & & .553 & & & \\
\hline Its access roads have at least two lanes & & & .533 & & & \\
\hline It makes shopping a social experience & & & & .861 & & \\
\hline It makes shopping an entertaining event & & & & .829 & & \\
\hline The centre has an attractive appearance & & & & .527 & & \\
\hline It offers extra services (maps, pram hire) & & & & & .735 & \\
\hline It has areas set aside for pedestrians only & & & & & .653 & \\
\hline It's quick \& easy to reach by public transport & & & & & & .833 \\
\hline Its retailers charge lower prices & & & & & & .426 \\
\hline Eigenvalues & $\mathbf{4 . 9 6}$ & $\mathbf{2 . 4 2}$ & $\mathbf{1 . 6 0}$ & $\mathbf{1 . 3 4}$ & $\mathbf{1 . 2 1}$ & $\mathbf{1 . 1 0}$ \\
\hline Cronbach Alpha Coefficient & $\mathbf{. 8 1}$ & $\mathbf{. 7 1}$ & $\mathbf{. 7 1}$ & $\mathbf{. 7 0}$ & $\mathbf{. 6 5}$ & $\mathbf{. 3 8}$ \\
\hline
\end{tabular}


The first factor, comprising a compact design, retail concentration, size of the centre and compatibility was labelled spatial convenience and explained $24.8 \%$ of the variance. Of significance to this study, the factor explaining the second largest degree of variance (12.1\%) was temporal convenience. While one-stop shopping and proximity could also be interpreted as spatial factors, consumers tend to interpret inter-centre travel more in terms of time than space (Neo and Wing, 2005). The third factor, comprising three parking attributes and two access attributes was labelled car convenience and explained $8.0 \%$ of the variance. The hedonic attributes that summarised the fourth factor, comprising entertainment, social and aesthetic attributes explained $6.7 \%$ of the variance. The fifth factor, comprising shopping services and the provision of pedestrian areas relates to effort convenience and explained $6.1 \%$ of the variance. The final factor explained $5.4 \%$ of the variance, and comprising just two attributes, public transport and price was labelled accordingly.

The six factors were then analysed using Cronbach alpha to test their reliability. Alpha scores above 0.65 are regarded as acceptable, particularly when there are fewer than ten items per construct and the scale is new (Loewenthal, 2001). Five of the six constructs yielded an alpha score ranging between .65 and .81, indicating they are reliable. The one exception was the public transport and price construct, which recorded an alpha score of just .38 and was therefore dropped from further analysis.

\section{Supply-side method}

Sampling frame

To facilitate comparison between the two phases of the study, the same geographic sampling frame used for the demand-side analysis was also used for the supply-side. This measure was taken to ensure the validity of the attitudinal concept was not compromised by respondents having no direct experience with the attitude object (Engel, Blackwell and Miniard, 1993). As the study included all community-level and regional-level retail centres within a fifteen-kilometre radius, it effectively provided a census of major retail centres within this geographic area. In all, the supply-side analysis included nineteen shopping strips and seventeen malls. Personal visits were made to all thirty-six retail centres to collect data on each of the attributes of time convenience.

\section{Operationalising the constructs}

One-stop shopping: One-stop shopping implies that all but the most esoteric of shopping needs can be satisfied in the one centre, all at the one time (Kaufman, 1996). While this may imply offering a mix capable of satisfying all consumer needs (Smith, 1956), such an interpretation brings with it the notion of mass and an associated increase in walking. Hence it involves trading off one form of convenience (time convenience) for another (spatial convenience). It was therefore necessary to develop a list of functions that would be capable of satisfying all but the most esoteric of shopping needs. This criterion implies that the list must have generic appeal and should therefore be based upon consumer preferences for each function. For this purpose, Bruwer's (1997) index of consumers' most preferred tenants was used to identify the functions necessary to provide for one-stop shopping (see tables 4 and 5).

Major department stores and supermarkets were used as replacement functions in the absence of specific stores. For example, a retail centre containing a supermarket but no green grocer, still offers the potential for one-stop shopping because a supermarket also sells fruit and vegetables. Major department stores fulfilled a similar role with books and sporting goods. Such an occurrence is noted by the symbol "*” (refer tables 4 and 5). 
This same symbol was also used to denote the presence of automatic teller machines substituting for a bank.

Analysis of the ability of shopping strips to provide for one-stop shopping did not include the tenant-mix of in-town malls. To combine the tenant-mixes would assume customer interchange between the two retail formats. This cannot be automatically assumed because patrons of in-town malls have been regularly observed to ignore the surrounding shopping strip, a phenomenon referred to as the 'fortress effect' (Lorch and Smith, 1993).

Trading hours: Data was recorded for each retail centre according to three criteria; (a) open Thursday and Friday until 9.00PM; (b) open Saturday until 4.00PM; and (c) open Sunday until 4.00 PM. Data on the trading hours of malls were gathered via the shoppers maps made available at the information desk or centre manager's office of each mall. For shopping strips, this information was obtained from the trading hours posted at the entrance of individual stores. With the exception of supermarkets, these trading hours were typically uniform.

Proximity: Proximity is defined as the distance between a retail centre and the consumer's place of home or work. In terms of proximity to home, it is a relative measure in that the distance between home and a retail centre varies according to where each individual resides. It is possible however to operationalise this construct at a more general level. The greater the population density surrounding a centre, the closer it is to a larger proportion of the residential population. Proximity to consumer households was therefore measured by examining each retail centre's location in the context of population density statistics for the geographic sampling frame.

Proximity to consumers' place of work was only measured for malls. Shopping strips at the community and regional level serve as major employment centres and therefore their proximity to a large working population is ensured. In fact, the 19 shopping strips serve as the largest employment centres in the geographic sampling frame. The proximity of malls to a large working population was therefore measured in terms of the number located within community and regional level shopping strips.

Enclosure: From a statistical perspective, the obvious means for determining the importance of enclosure is to compare shopping strips and malls against some statistical measure of retail performance. All seventeen malls are enclosed and all nineteen shopping strips are primarily open-air structures. The problem lies in the fact that enclosure is only one of many attributes that set the mall and the shopping strip apart. Greater statistical insight can be gleaned instead by comparing the enclosed and openair sectors of the shopping strip. Due to the absence of sales data, basic measures of economic blight such as vacancy levels and retail composition were used as comparison points (Berry, 1963). The shopping strip offers two basic forms of enclosure: the arcade and the skywalk. An arcade is a covered pedestrian way typically used to link busy thoroughfares. It has shops on either side, and is characterised by a narrow width that provides space for shoppers but not cars (Northen and Haskell, 1977). A skywalk is a network of elevated interconnecting pedestrian walkways that offer climate control (Robertson, 1988). There were no skywalks in the geographic sampling frame. 


\section{Analysis}

Retail centre preference

In order to establish an attitudinal measure for further analysis, respondents were asked to indicate their preferred retail centre. Their preference for shopping strips (44.3\%) and shopping centres (44.7\%) was almost identical, with a further $11 \%$ of respondents holding no specific preference. This finding is consistent with Howell and Roger's (1980) proposition that consumer patronage decisions between shopping strips and shopping centres lay at opposite ends of a preference map, with consumers typically preferring one retail format but not both.

Research question 1: How important is time convenience in determining consumers' retail centre preference?

Of the five factors, consumers rated time convenience as the most important determinant of where they decide to shop (table 2). In fact, with a scale mid-point value of four, all convenience factors with the exception of effort are regarded as important. Significantly, the hedonic factor $(\underline{M}=3.78)$ falls below this mid-point, and hence in a multipurpose shopping context, does not serve as a salient influence over patronage.

Table 2: The relative importance of time convenience

\begin{tabular}{|l|c|c|c|c|c|}
\hline Factor & $\underline{\mathbf{M}}$ & $\underline{\mathbf{S D}}$ & $\mathbf{T}$ & $\mathbf{D F}$ & $\mathbf{P}$ \\
\hline Time convenience & 5.40 & 1.3 & 25.5 & 528 & $<.001$ \\
\hline Car convenience & 5.38 & 1.0 & 29.3 & 476 & $<.001$ \\
\hline Spatial convenience & 4.79 & 1.4 & 13.2 & 524 & $<.001$ \\
\hline Hedonic shopping & 3.78 & 1.4 & -3.6 & 533 & $<.001$ \\
\hline Effort convenience & 3.77 & 1.7 & -3.1 & 524 & .002 \\
\hline
\end{tabular}

Research question \#2: Is the importance of time convenience limited to a smaller subset of the population?

One-way ANOVA tests were used to explore the consistency of consumer attitudes towards time convenience across age and income. For age, respondents were divided into three groups; 18-40 years old, 41-60 years old and 61+ years old, and for income, into lower, middle and upper income groups. Analysis revealed no statistically significant differences for either age $[F(2,526)=2.2, p=.11]$ or income $[F(2,462)=2.4, p=.09]$.

Independent samples t-tests were used to compare attitudes across gender and retail centre preference. While analysis found no significant difference between males $(M=5.4$, $\underline{\mathrm{SD}}=1.1)$ and females $(\underline{M}=5.4, \underline{S D}=1.4 ; \mathrm{t}(479)=0.04, \mathrm{p}=.97)$, there was for retail centre preference. Respondents that prefer malls $(\underline{M}=5.8, \underline{S D}=1.1)$ assign significantly more importance to time convenience than those that prefer shopping strips $(\underline{M}=5.1, \underline{S D}=1.3$; $t(440)=6.3, p=<.001)$.

Research question 3: How does time convenience influence retail centre preference?

This question was addressed via a direct logistic regression analysis using retail centre preference as the outcome. The categorical variables of age, income, gender and location, along with the five factors served as the predictors. Of the 342 cases available for analysis, 164 preferred shopping strips and 178 preferred shopping malls. A test of 
the model against a constant-only model was statistically reliable, $X^{2}(D F=11, \underline{N}=342)=$ $69.7, \underline{\mathrm{p}}<.001$, indicating that the predictors as a set, reliably distinguish between the two groups. Prediction success was relatively impressive, with $62 \%$ of those preferring shopping strips and $73 \%$ of those preferring shopping malls correctly predicted, for an overall success rate of $68 \%$.

Table 3 provides summary statistics for the two predictors that significantly predicted retail centre preference $(p<.05)$. Of the four categorical variables tested, the model indicates that retail centre preference can be predicted by location $(\underline{z}=5.5, \underline{p}=.019)$, with shoppers from the mall-dominated north-east zone more likely to prefer shopping malls. It can also be predicted by the importance assigned to time convenience ( $\underline{z}=14.1$, $\underline{p}=<.001)$, with those that prefer shopping malls $(\underline{M}=5.8)$ assigning greater importance to it than those that prefer shopping strips $(\underline{M}=5.1)$. Hence, although time sensitivity may not serve as a strong predictor of retail centre preference (LeHew and Cushman, 1998), the importance assigned to time-saving attributes does.

Table 3: Logistic regression analysis of retail centre preference as a function of attitudinal and demographic variables

\begin{tabular}{|l|l|l|l|l|l|c|c|}
\hline Variable & $\begin{array}{l}\text { Beta } \\
\text { Coefficient }\end{array}$ & $\begin{array}{l}\text { Standard } \\
\text { Error }\end{array}$ & $\begin{array}{l}\text { Wald } \\
\text { Statistic }\end{array}$ & Sig. & Exp(B) & $\begin{array}{l}\text { 95\% C.I } \\
\text { Lower }\end{array}$ & $\begin{array}{l}\text { 95\% C.I } \\
\text { Upper }\end{array}$ \\
\hline Time convenience & .466 & .124 & 14.1 & $<.001$ & 1.59 & 1.25 & 2.03 \\
\hline Location & .878 & .373 & 5.5 & .019 & 2.41 & 1.16 & 5.00 \\
\hline
\end{tabular}

Research question 4: How do malls and shopping strips compare in the provision of time convenience?

One-stop shopping: The tendency for malls to be anchored by a department store and/or supermarket meant that fifteen of the seventeen (88\%) were able to offer all eleven functions (table 4). The two malls unable to offer one-stop shopping were amongst the smallest, with North Blackburn containing just 45 businesses and Oakleigh just 53.

Table 4: The provision of one-stop shopping in malls

\begin{tabular}{|l|c|c|c|c|c|c|c|c|c|c|c|c|c|c|c|c|c|}
\hline Function & $\mathbf{1}$ & $\mathbf{2}$ & $\mathbf{3}$ & $\mathbf{4}$ & $\mathbf{5}$ & $\mathbf{6}$ & $\mathbf{7}$ & $\mathbf{8}$ & $\mathbf{9}$ & $\mathbf{1 0}$ & $\mathbf{1 1}$ & $\mathbf{1 2}$ & $\mathbf{1 3}$ & $\mathbf{1 4}$ & $\mathbf{1 5}$ & $\mathbf{1 6}$ & $\mathbf{1 7}$ \\
\hline Supermarket & 1 & 2 & 2 & 2 & 3 & 1 & 2 & 2 & 2 & 2 & 3 & 2 & 2 & 1 & 3 & 2 & 3 \\
\hline Bakery & 4 & 1 & 2 & 2 & 2 & 1 & 1 & 2 & 5 & 4 & 1 & 1 & 1 & 1 & 2 & 3 & 3 \\
\hline Butcher & 4 & $\star$ & 2 & 3 & 1 & 2 & 1 & 2 & 1 & 1 & 1 & 1 & 1 & 1 & 1 & 1 & 2 \\
\hline Chemist & 2 & 3 & 1 & 2 & 2 & 1 & 1 & 1 & 4 & 2 & 2 & 1 & 2 & 1 & 1 & 3 & 2 \\
\hline Café & 3 & 15 & 11 & 2 & 12 & 1 & 2 & 4 & 25 & 10 & 11 & 2 & 11 & 1 & 8 & 15 & 3 \\
\hline Bank & 1 & 6 & $\star$ & 1 & 4 & 1 & $\star$ & 4 & 7 & 7 & 3 & $\star$ & 4 & $\star$ & 4 & 6 & $*$ \\
\hline Fashion (Female) & 8 & 36 & 28 & 6 & 28 & 5 & 9 & 8 & 66 & 22 & 27 & 6 & 27 & 9 & 19 & 47 & 4 \\
\hline Fashion (Male) & 4 & 17 & 17 & 1 & 16 & 1 & 1 & 2 & 31 & 9 & 12 & 1 & 8 & 1 & 10 & 28 & 1 \\
\hline Shoes & 1 & 12 & 9 & $\mathbf{0}$ & 9 & 1 & 2 & 3 & 13 & 5 & 6 & 1 & 8 & 4 & 4 & 12 & 2 \\
\hline Books & 1 & 3 & 3 & $\mathbf{0}$ & 3 & 1 & 2 & 1 & 4 & 2 & 2 & 1 & 3 & 1 & 1 & 3 & $*$ \\
\hline Sporting & 2 & 4 & 2 & $\mathbf{0}$ & 3 & 1 & $\star$ & $\star$ & 5 & 1 & 1 & $\mathbf{0}$ & 2 & $\star$ & 3 & 3 & $*$ \\
\hline
\end{tabular}

KEY: 1=Box Hill Central, 2=Doncaster, 3=Greensborough, 4=North Blackburn, 5=Northland, 6=Warringal SC, 7=Whitehorse Plaza, 8=Brandon Park, 9=Chadstone, 10=Forest Hill, 11=The Glen, 12=Oakleigh, 13=Southland, 14=Malvern Central, 15=Airport West, 16=Highpoint, $17=$ Northcote. 
The potential flaws associated with leaving the formulation of the tenant-mix to market forces became evident in the analysis of shopping strips. Despite comprising 212 businesses, Oakleigh could offer 7 bakeries, but no supermarket, book or sports store. Richmond could offer 88 women's clothing stores within its 210 businesses but failed to satisfy five of the other ten criteria. Footscray offers 359 businesses but no supermarket in its shopping strip. In all, only nine of the seventeen shopping strips could provide for all eleven functions (table 5). As is to be expected, larger shopping strips are more likely to provide for one-stop shopping. Moonee Ponds, for example, was the only shopping strip with fewer than 200 businesses to offer all eleven functions.

Table 5: The provision of one-stop shopping in shopping strips

\begin{tabular}{|l|c|c|c|c|c|c|c|c|c|c|c|c|c|c|c|c|c|c|c|}
\hline Function & $\mathbf{1}$ & $\mathbf{2}$ & $\mathbf{3}$ & $\mathbf{4}$ & $\mathbf{5}$ & $\mathbf{6}$ & $\mathbf{7}$ & $\mathbf{8}$ & $\mathbf{9}$ & $\mathbf{1 0}$ & $\mathbf{1 1}$ & $\mathbf{1 2}$ & $\mathbf{1 3}$ & $\mathbf{1 4}$ & $\mathbf{1 5}$ & $\mathbf{1 6}$ & $\mathbf{1 7}$ & $\mathbf{1 8}$ & $\mathbf{1 9}$ \\
\hline Supermarket & $\mathbf{0}$ & 2 & 1 & 1 & 1 & $\mathbf{0}$ & 2 & 2 & 1 & 1 & 1 & 3 & 1 & 2 & 1 & $\mathbf{0}$ & 1 & $\mathbf{0}$ & $\mathbf{0}$ \\
\hline Bakery & 5 & 7 & 7 & 5 & 1 & 7 & 4 & 2 & 6 & 7 & 7 & 8 & $\star$ & 8 & 8 & 7 & 8 & 4 & $\mathbf{0}$ \\
\hline Butcher & 2 & 4 & 1 & 6 & 1 & 5 & 3 & 2 & 4 & 2 & 4 & 3 & 1 & 7 & 5 & 3 & $\star$ & 2 & $\mathbf{0}$ \\
\hline Chemist & 2 & 6 & 3 & 2 & 3 & 2 & 2 & 2 & 4 & 2 & 4 & 5 & 2 & 3 & 2 & 7 & 5 & 1 & $\mathbf{0}$ \\
\hline Café & 10 & 9 & 10 & 4 & 3 & 5 & 10 & 9 & 8 & 10 & 7 & 19 & 18 & 4 & 13 & 6 & 11 & 5 & 18 \\
\hline Bank & 4 & 4 & 8 & 4 & 2 & 4 & 6 & 4 & 6 & 5 & 7 & 6 & 2 & 5 & 4 & 7 & 5 & 3 & 3 \\
\hline Fashion (F) & 17 & 14 & 36 & 2 & 3 & 12 & 23 & 6 & 15 & 17 & 19 & 10 & 88 & 15 & 1 & 17 & 22 & 5 & 88 \\
\hline Fashion (M) & 6 & 4 & 11 & 6 & 1 & 7 & 8 & $\mathbf{0}$ & 6 & 7 & 3 & 5 & 49 & 6 & 5 & 4 & 8 & 1 & 36 \\
\hline Shoes & 3 & 5 & 10 & 2 & 3 & 2 & 3 & 1 & 5 & 1 & 3 & 4 & 10 & 3 & 4 & 8 & 5 & 1 & 9 \\
\hline Books & 1 & 2 & 5 & 1 & $\mathbf{0}$ & $\mathbf{0}$ & 2 & $\mathbf{0}$ & 2 & 1 & 4 & 1 & 1 & $\mathbf{0}$ & 2 & $\star$ & 3 & $\mathbf{0}$ & $\mathbf{0}$ \\
\hline Sporting & $\mathbf{0}$ & 1 & $\star$ & $\mathbf{0}$ & $\mathbf{0}$ & $\mathbf{0}$ & 2 & $\mathbf{0}$ & $\mathbf{0}$ & $\mathbf{0}$ & 1 & 1 & 1 & 1 & $\mathbf{0}$ & 1 & 3 & 1 & 1 \\
\hline
\end{tabular}

KEY: 1=Ivanhoe, 2=Bentleigh, 3=Camberwell, 4=Carnegie, 5=Moorabbin, 6=Oakleigh, 7=Brighton, 8=Brighton Nth, 9=Elsternwick, 10=Hampton, 11=Malvern, 12=Prahran, 13=South Yarra, 14=Coburg, 15=Fitzroy, 16=Footscray, 17=Moonie Ponds, 18=Northcote, 19=Richmond.

It must be remembered however that analysis of shopping strips ignored the tenant-mix of in-town malls. Northcote and Oakleigh shopping strips both contain in-town malls. The fortress effect serves as a real threat for both, with Northcote Mall providing all eleven functions, and Oakleigh Mall offering all but sporting goods. However in shopping strips such as Richmond, Footscray and Ivanhoe, their in-town malls are neighbourhood centres, and therefore too small to prevent a consumer spill-over into the surrounding strip. In the case of Footscray and Ivanhoe, both neighbourhood malls contain a supermarket meaning that their retail centres as a whole offer one-stop shopping. Thus the gap between shopping strips and malls in the provision of one-stop shopping may not be as significant as first indicated.

Trading hours: Analysis revealed that thirteen of the nineteen shopping strips are unable to satisfy any of the three criteria for extended trading hours (table 6). Subsequently, their trading hours are limited to 9.00 AM to 5.00 PM Monday to Friday, and 9.00 AM to 1.00PM on Saturday. This provides potential problems for the shopping strip patron. Firstly, it forces them to shop during the busiest times of the day, which in combination with traffic congestion and limited parking opportunities has the potential to increase the temporal and effort costs of shopping. Secondly, it alienates what is likely to be one of the largest and most affluent consumer segments, the dual income family. By coinciding the close of retail trade with the close of business, shopping strips are ignoring the tendency for consumers to combine shopping with work trips. In effect, many of their stores are closing at the precise time some of the most affluent consumers want to shop. If the consumer chooses not to shop, or is unable to shop, during their lunch breaks or 
on Saturday morning, the limited trading hours of the shopping strip virtually forces the working consumer to patronise malls.

Table 6: The provision of extended trading hours across the two retail formats

\begin{tabular}{|c|c|c|c|c|c|c|c|}
\hline Shopping Strip & A & B & C & Mall & A & B & C \\
\hline Ivanhoe & - & - & - & Box Hill Central & * & * & * \\
\hline Bentleigh & - & - & - & Doncaster SC & * & * & * \\
\hline Camberwell & - & * & - & Greensborough & * & * & * \\
\hline Carnegie & - & - & - & North Blackburn & * & * & - \\
\hline Moorabbin & - & - & - & Northland & * & * & * \\
\hline Oakleigh & - & - & - & Warringal SC & * & * & * \\
\hline Brighton & - & * & - & Whitehorse Plaza & * & * & * \\
\hline Brighton Nth & - & - & - & Brandon Park & * & * & * \\
\hline Elsternwick & - & - & - & Chadstone & * & * & * \\
\hline Hampton & - & - & - & Forest Hill & * & * & * \\
\hline Malvern & - & - & - & The Glen & * & * & * \\
\hline Prahran & - & - & - & Oakleigh & * & * & * \\
\hline South Yarra & - & * & * & Southland & * & * & * \\
\hline Coburg & - & - & - & Malvern Central & * & * & * \\
\hline Fitzroy & - & - & - & Airport West & * & * & * \\
\hline Footscray & - & * & - & Highpoint & * & * & * \\
\hline Moonie Ponds & - & * & - & Northcote & * & * & * \\
\hline Northcote & - & - & - & & & & \\
\hline Richmond & - & * & * & & & & \\
\hline
\end{tabular}

KEY: A = Open Thursday and Friday until 9.00PM, B = Open Saturday until 4.00PM, C = Open Sunday until 4.00 PM.

In stark contrast, North Blackburn is the only mall that did not meet all three criteria for extended trading hours. This provides the mall with several potential advantages. Firstly, the days during which its hours are most extensive, Thursday to Saturday, coincide with the days where shopping activity is at its greatest (East, Lomax, Willson and Harris, 1994). Most importantly, the longer trading hours on weekends and the fact that it often remains open on public holidays, allows the mall to target recreational shoppers.

Proximity: Due to the mixed-use nature of most shopping strips and their sheer size, they serve as large employment centres in their own right, guaranteeing proximity to many consumers place of work. Moreover, all nineteen shopping strips are located in areas of relatively high population density, containing at least 2500 residents per square kilometre (Australian Bureau of Statistics, 2006) thereby offering proximity to large residential populations (table 7 ). In contrast, only six of the seventeen malls are located within shopping strips, meaning that most are located away from large working populations. Furthermore, eight of the eleven out-of-town malls are located in less densely populated urban areas (less than 2500 residents per square kilometre). As such, the shopping strip enjoys a comparative advantage in terms of proximity.

Enclosure: Analysis of both the enclosed and open-air sectors of the shopping strip offers anecdotal evidence that enclosure offers limited value. Just $4.8 \%$ of businesses across the nineteen shopping strips are enclosed within arcades. In all, there are twentytwo arcades spread across fourteen of the nineteen shopping strips (table 8). Several contrasts separate the enclosed and open areas of shopping strips. The predominant function in the open-air shopping strip is fashion (17\%), followed by professional services 
(16\%), leisure products (13\%) and consumer services (13\%). Hence, two of its four largest functions - fashion and leisure products - serve as key attractors.

Table 7: Location and population density for shopping strips and malls

\begin{tabular}{|l|c|l|c|c|}
\hline Shopping Strip & Density & Mall & Density & Location \\
\hline Ivanhoe & $2500-4000$ & Box Hill Central & $2500-4000$ & Town Centre \\
\hline Bentleigh & $2500-4000$ & Doncaster SC & $2500-4000$ & Out-of-town \\
\hline Camberwell & $4000-7500$ & Greensborough & $1500-2500$ & Town Centre \\
\hline Carnegie & $2500-4000$ & North Blackburn & $1500-2500$ & Out-of-town \\
\hline Moorabbin & $2500-4000$ & Northland & $4000-7500$ & Out-of-town \\
\hline Oakleigh & $2500-4000$ & Warringal SC & $2500-4000$ & Out-of-town \\
\hline Brighton & $2500-4000$ & Whitehorse Plaza & $2500-4000$ & Town Centre \\
\hline Brighton North & $2500-4000$ & Brandon Park & $0-1500$ & Out-of-town \\
\hline Elsternwick & $2500-4000$ & Chadstone & $1500-2500$ & Out-of-town \\
\hline Hampton & $2500-4000$ & Forest Hill & $1500-2500$ & Out-of-town \\
\hline Malvern & $4000-7500$ & The Glen & $1500-2500$ & Out-of-town \\
\hline Prahran & $4000-7500$ & Oakleigh & $2500-4000$ & Town Centre \\
\hline South Yarra & $4000-7500$ & Southland & $1500-2500$ & Out-of-town \\
\hline Coburg & $4000-7500$ & Malvern Central & $4000-7500$ & Town Centre \\
\hline Fitzroy & $4000-7500$ & Airport West & $0-1500$ & Out-of-town \\
\hline Footscray & $4000-7500$ & Highpoint & $1500-2500$ & Out-of-town \\
\hline Moonie Ponds & $2500-4000$ & Northcote & $4000-7500$ & Town Centre \\
\hline Northcote & $4000-7500$ & & & \\
\hline Richmond & $4000-7500$ & & & \\
\hline KEY: Density & Poptlan & & &
\end{tabular}

KEY: Density = Population density per square kilometre

Table 8: Percentage composition of functions in open-air sectors of shopping strips

\begin{tabular}{|l|c|c|c|c|c|c|c|c|c|c|c|c|c|c|c|}
\hline Function & $\underline{\mathbf{1}}$ & $\mathbf{2}$ & $\underline{\mathbf{3}}$ & $\underline{\mathbf{4}}$ & $\underline{\mathbf{5}}$ & $\underline{\mathbf{6}}$ & $\mathbf{\mathbf { 7 }}$ & $\underline{\mathbf{8}}$ & $\underline{\mathbf{9}}$ & $\underline{\mathbf{1 0}}$ & $\underline{\mathbf{1 1}}$ & $\frac{\mathbf{1 2}}{0}$ & $\underline{\mathbf{1 3}}$ & $\frac{\mathbf{1 4}}{0}$ & Average \\
\hline Department & 0 & 0 & 0 & 0 & 0 & 0 & 0 & 0 & 0 & 0 & 0 & 0 & $\mathbf{0}$ \\
\hline Supermarket & 0 & 1 & 0 & 1 & 1 & 1 & 1 & 1 & 0 & 0 & 0 & 1 & 0 & 1 & $\mathbf{1}$ \\
\hline Food/Health & 7 & 10 & 5 & 7 & 12 & 16 & 9 & 5 & 1 & 7 & 12 & 17 & 9 & 9 & $\mathbf{9}$ \\
\hline Food Service & 13 & 18 & 12 & 14 & 10 & 9 & 12 & 9 & 16 & 13 & 15 & 7 & 14 & 10 & $\mathbf{1 2}$ \\
\hline Homeware & 10 & 15 & 12 & 5 & 7 & 5 & 8 & 3 & 6 & 7 & 10 & 7 & 5 & 8 & $\mathbf{8}$ \\
\hline HW/Gar/Auto & 1 & 2 & 1 & 2 & 3 & 4 & 1 & 4 & 0 & 1 & 1 & 1 & 1 & 2 & $\mathbf{2}$ \\
\hline Fashion & 7 & 10 & 22 & 10 & 12 & 8 & 20 & 4 & 58 & 15 & 12 & 13 & 17 & 30 & $\mathbf{1 7}$ \\
\hline Leisure/Gift & 12 & 17 & 14 & 13 & 14 & 12 & 12 & 13 & 9 & 14 & 12 & 12 & 9 & 18 & $\mathbf{1 3}$ \\
\hline Prof Ser & 18 & 9 & 15 & 22 & 18 & 16 & 21 & 28 & 3 & 17 & 15 & 14 & 23 & 7 & $\mathbf{1 6}$ \\
\hline Cons Ser & 19 & 13 & 12 & 18 & 13 & 17 & 13 & 15 & 3 & 15 & 12 & 9 & 13 & 6 & $\mathbf{1 3}$ \\
\hline Comm. Ser & 6 & 4 & 3 & 4 & 5 & 5 & 3 & 7 & 0 & 3 & 2 & 7 & 7 & 3 & $\mathbf{4}$ \\
\hline Vacant & 6 & 1 & 3 & 3 & 7 & 6 & 3 & 11 & 2 & 9 & 9 & 12 & 2 & 5 & $\mathbf{6}$ \\
\hline TOTAL & $\mathbf{1 0 0}$ & $\mathbf{1 0 0}$ & $\mathbf{1 0 0}$ & $\mathbf{1 0 0}$ & $\mathbf{1 0 0}$ & $\mathbf{1 0 0}$ & $\mathbf{1 0 0}$ & $\mathbf{1 0 0}$ & $\mathbf{1 0 0}$ & $\mathbf{1 0 0}$ & $\mathbf{1 0 0}$ & $\mathbf{1 0 0}$ & $\mathbf{1 0 0}$ & $\mathbf{1 0 0}$ & $\mathbf{1 0 0}$ \\
\hline
\end{tabular}

KEY: 1=Northcote, 2=Prahran, 3=Camberwell, 4=North Brighton, 5=Bentleigh, 6=Carnegie, 7=Brighton, 8=Moorabbin, 9=South Yarra, 10=Malvern, 11=Footscray, 12=Coburg, 13=Ivanhoe, 14=Moonie Ponds.

In contrast, the two most predominant functions in arcades (table 9) are professional services (23\%) and consumer services (20\%). The third most common business in an arcade is an empty one, with vacancies making up $17 \%$ of all arcade sites. This compares poorly with the open-air shopping strip where just $6 \%$ of its sites lie vacant. Food services (13\%) heavily dominated by small, independent fast food stores, round out the four most common functions found in arcades. Analysis therefore revealed two key findings. Firstly, $60 \%$ of all sites within the enclosed sectors of shopping strips do not 
in fact offer shopping functions. Instead they either offer service functions or they lie vacant. Secondly, based on the principles of Bid Rent Theory, the predominance of service functions indicates that by attracting lower rental functions, arcades do not serve as popular retail structures. This suggests that arcades are not attractive to consumers. If they were, competition for these limited sites would push rentals beyond a level that service providers could profitably afford (Brown, 1994).

Table 9: Percentage composition of functions in enclosed sectors of shopping strips

\begin{tabular}{|l|c|c|c|c|c|c|c|c|c|c|c|c|c|c|c|}
\hline Function & $\underline{\mathbf{1}}$ & $\underline{\mathbf{2}}$ & $\underline{\mathbf{3}}$ & $\underline{\mathbf{4}}$ & $\underline{\mathbf{5}}$ & $\underline{\mathbf{6}}$ & $\underline{\mathbf{7}}$ & $\underline{\mathbf{8}}$ & $\underline{\mathbf{9}}$ & $\underline{\mathbf{1 0}}$ & $\underline{\mathbf{1 1}}$ & $\underline{\mathbf{1 2}}$ & $\underline{\mathbf{1 3}}$ & $\underline{\mathbf{1 4}}$ & Average \\
\hline Department & 0 & 0 & 0 & 0 & 0 & 0 & 0 & 0 & 0 & 0 & $\mathbf{2}$ & 0 & 0 & 0 & $\mathbf{0 . 1}$ \\
\hline Supermarket & 0 & 0 & 0 & 0 & 0 & 0 & 0 & 0 & 0 & 0 & 0 & 0 & 0 & 0 & $\mathbf{0}$ \\
\hline Food/Health & 0 & 0 & 5 & 0 & 0 & 20 & 33 & 4 & 0 & 17 & 4 & 8 & 0 & 0 & $\mathbf{7}$ \\
\hline Food Service & 0 & 0 & 35 & 50 & 0 & 20 & 0 & 4 & 0 & 17 & 4 & 11 & 13 & 25 & $\mathbf{1 3}$ \\
\hline Homeware & 0 & 0 & 0 & 0 & 0 & 0 & 0 & 0 & 0 & 0 & 2 & 5 & 4 & 0 & $\mathbf{1}$ \\
\hline HW/Gar/Auto & 0 & 0 & 0 & 0 & 0 & 0 & 0 & 4 & 0 & 0 & 0 & 0 & 0 & 0 & $\mathbf{0}$ \\
\hline Fashion & 0 & 0 & 25 & 0 & 0 & 20 & 0 & 9 & 0 & 0 & 10 & 22 & 13 & 0 & $\mathbf{7}$ \\
\hline Leisure/Gift & 0 & 20 & 15 & 0 & 20 & 0 & 0 & 4 & 11 & 8 & 0 & 11 & 17 & 13 & $\mathbf{9}$ \\
\hline Prof Ser & 40 & 40 & 0 & 25 & 60 & 0 & 33 & 30 & 33 & 8 & 16 & 8 & 26 & 0 & $\mathbf{2 3}$ \\
\hline Cons Ser & 20 & 0 & 15 & 25 & 20 & 0 & 33 & 22 & 33 & 17 & 6 & 19 & 17 & 50 & $\mathbf{2 0}$ \\
\hline Comm. Ser & 0 & 0 & 0 & 0 & 0 & 20 & 0 & 0 & 0 & 17 & 2 & 3 & 4 & 13 & $\mathbf{4}$ \\
\hline Vacant & 40 & 40 & 5 & 0 & 0 & 20 & 0 & 22 & 22 & 17 & 54 & 14 & 4 & 0 & $\mathbf{1 7}$ \\
\hline TOTAL & $\mathbf{1 0 0}$ & $\mathbf{1 0 0}$ & $\mathbf{1 0 0}$ & $\mathbf{1 0 0}$ & $\mathbf{1 0 0}$ & $\mathbf{1 0 0}$ & $\mathbf{1 0 0}$ & $\mathbf{1 0 0}$ & $\mathbf{1 0 0}$ & $\mathbf{1 0 0}$ & $\mathbf{1 0 0}$ & $\mathbf{1 0 0}$ & $\mathbf{1 0 0}$ & $\mathbf{1 0 0}$ & $\mathbf{1 0 0}$ \\
\hline
\end{tabular}

KEY: 1=Northcote, 2=Prahran, 3=Camberwell, 4=North Brighton, 5=Bentleigh, 6=Carnegie, 7=Brighton, 8=Moorabbin, 9=South Yarra, 10=Malvern, 11=Footscray, 12=Coburg, 13=Ivanhoe, 14=Moonie Ponds.

To provide further insight into the importance of enclosure, an independent samples ttest was conducted. It indicated that respondents that prefer malls $(\underline{M}=5.8, \underline{S D}=1.4)$ assign significantly more importance to enclosure than those that prefer shopping strips $(\mathrm{M}=4.6, \mathrm{SD}=1.9 ; \mathrm{t}(515)=31.1, \mathrm{p}=<.001)$. Moreover, whereas the former rank it as their sixth most important individual attribute, the latter ranks it eleventh. Hence both the supply-side and demand-side analysis suggest that enclosure is unlikely to provide the mall with any significant means of gaining market share at the expense of the shopping strip.

\section{Conclusion}

Due to increasing time-scarcity, a growing number of shoppers are likely to seek timebuying solutions. One such solution is for retail centres to offer time convenience via one-stop shopping, extended trading hours, an enclosed environment and locations that are close to where consumers live or work. This study found that in a comparison of five factors, time convenience served as the most important determinant of retail centre patronage. The overall attitude that time convenience is important, is consistent across age, income, gender and retail centre preference, suggesting its salient influence is somewhat universal. In spite of the fact those that prefer malls and those that prefer shopping strips both regard time convenience as important, the former is distinguished by the added salience they assign it.

Consistent with this notion, malls and strips were found to differ in their provision of time convenience attributes. Malls hold a relative advantage in terms of one-stop shopping and extended trading hours, while shopping strips are more likely to be located close to where consumers live or work. In contrast, the implications relating to enclosure are not as straightforward. Enclosure serves as a salient attribute for consumers, and in this regard the mall holds an advantage. However this should not be interpreted as implying 
that shopping strips should seek to close this gap. This is because those that prefer shopping strips assign less importance to this attribute, and this is reflected by the fact that the enclosed areas of shopping strips show symptoms of retail blight as evidenced by the high proportion of lower-order businesses and vacant sites.

\section{Future research}

While the link between time-convenience, one-stop shopping, extended trading hours and proximity is a straightforward one, the same cannot be said for enclosure. Nor can the association of enclosure with these other time-buying attributes be considered an anomaly. Reimers and Clulow (2008A; 2008B) found the same factor emerged when measured in the separate contexts of the meaning of convenience and the importance assigned to it. Hence further research is necessary to explain such a relationship. One possible explanation is that while the three other attributes serve as time-saving solutions, the ability of enclosure to provide a pleasant environment that encourages shoppers to relax and enjoy the shopping experience itself, means it may serve as a time-distracter.

A significant finding stemming from this study was that the importance assigned to time convenience was consistent across demographic variables such as age, income and gender. Previous research has also suggested that its appeal is unlikely to be limited to utilitarian shoppers. The finite nature of time and its growing scarcity means that the long accepted notion that hedonic shoppers are characterised by their willingness to dedicate leisure time to shopping may be the right answer to the wrong question. Perhaps rather than focusing on whether they are willing to spend leisure time shopping, the question should be are they able? Further research is therefore necessary to measure whether the importance of time convenience varies according to utilitarian or hedonic shopping motives.

\section{References}

Acland, H. (2000), "Slowing down the speeding shopper", Marketing, March $16^{\text {th }}$, pp. 2526.

Alreck, P., and Settle, R. (2002), "The hurried consumer: Time-saving perceptions of Internet and catalogue shopping", Journal of Database Marketing, Vol. 10, No. 1, pp. 2535.

Anselmsson, J. (2006), "Sources of customer satisfaction with shopping malls: A comparative study of different customer segments", International Review of Retail, Distribution and Consumer Research, Vol. 16, No. 1, pp. 115-38.

Arentze, T., Oppewal, H., and Timmermans, H. (2005), "A multipurpose shopping trip model to assess retail agglomeration effects", Journal of Marketing Research, Vol. 42, No. 1, pp. 109-115.

Arentze, T., and Timmermans, H. (2005), "An analysis of context and constraintsdependent shopping behavior using qualitative decision principles", Urban Studies, Vol. 42, No. 3, pp. 435-48.

Assael, H. (1992), Consumer Behavior and Marketing Action, 4th edition, PWS-Kent, Boston. 
Assael, H., Reed, P., and Patton, M. (1995), Marketing Principles and Strategy, Australian edition, Harcourt Brace, Sydney.

Australian Bureau of Statistics, (2006), Melbourne ... A social atlas, Canberra.

Balazs, A. (1994), "The Eldermall: Exploring new ways to position the aging retail shopping centre for aging consumers", Journal of Shopping Center Research, Vol. 1, No. 1, pp. 39-59.

Balazs, A. (1995), "Positioning the retail shopping centre", Stores, Vol. 77, No. 4, pp. RR10-11.

Berry, B. (1963), "Commercial structure and commercial blight", Department of Geography Research Paper, No. 85, Chicago.

Beyard, M., Braun, R., McLaughlin, H., Phillips, P., and Rubin, M. (2001), Developing Retail Entertainment Destinations, Urban Land Institute, Washington.

Brown, S. (1994), "Retail location at the Micro-Scale: Inventory and Prospect", The Service Industries Journal, Vol. 14, No. 4, pp. 542-76.

Bruwer, J. (1997), "Solving the ideal tenant mix puzzle for a proposed shopping centre: a practical research methodology", Property Management, Vol. 15, No. 3, pp. 160-72.

Carpenter, J. (2008), "Demographics and patronage motives of supercenter shoppers in the United States", International Journal of Retail and Distribution Management, Vol. 36, No. 1, pp. 5-16.

Coleman, P. (2006), Shopping environments: Evolution, planning and design, Architectural Press, Sydney.

Csaba, F., and Askegaard, S. (1999), "Malls and the orchestration of the shopping experience in a historical perspective", Advances in Consumer Research, Vol. 26, No. 1, pp. 34-40.

Dennis, C., Newman, A., and Marsland, D. (2005), Objects of desire: Consumer behavior in Shopping Centre Choices, Palgrave, Britain.

Dholakia, R. (1999), "Going shopping: key determinants of shopping behaviours and motivations", International Journal of Retail and Distribution Management, Vol. 27, No. 4, pp. $154-65$

Doubilet, S. (1999), "Reinventing the mall", Architectural Record, Vol. 187, No. 10, pp. 151-53.

East, R., Lomax, W., Willson, G., and Harris, P. (1994), "Decision making and habit in shopping times", European Journal of Marketing, Vol. 28, No. 4, pp. 56-71.

Engel, J., Blackwell, R., and Miniard, P. (1993), Consumer Behavior, 7th edition, Dryden Press, U.S.A 
Eppli, M., and Shilling, J. (1997), "How critical is a good location to a regional shopping center?", Journal of Shopping Center Research, Vol. 4, No. 1, pp. 97-111.

Farrell, J. (2003), One nation under goods, Smithsonian Books, Washington.

Fast, J., and Frederick, J. (1998), "The time of our lives: Juggling work and leisure over the life cycle", Statistics Canada, Catalogue No. 89-584-MIE - No. 4, Housing, Family and Social Statistics Division, Ottawa.

Fitch, D. (2004), "Measuring convenience: Scot's perceptions of local food and retail provision", International Journal of Retail and Distribution Management, Vol. 32, No. 2, pp. 100-08.

Frasquet, M., Gil, I., and Molla, A. (2001), "Shopping-centre selection modelling: A segmentation approach", International Review of Retail, Distribution and Consumer Research, Vol. 11, No. 1, pp. 23-38.

Geiger, S. (2007), "Exploring night-time grocery shopping behaviour", Journal of Retailing and Consumer Services, Vol. 14, No. 1, pp. 24-34.

Gorter, C., Nijkamp, P., and Klamer, P. (2003), "The attraction force of out-of-town shopping malls: A case study on the run-fun shopping in the Netherlands", Tijdschrift voor Economische en Sociale Geografie, Vol .94, No. 2, pp. 219-29.

Gruen, V., and Smith, L. (1960), Shopping Towns USA: The planning of shopping centers, Van Nostrand Reinhold, Melbourne.

Hackett, P., and Foxall, G. (1994), "A factor analytic study of consumers' location specific values: A traditional high street and a modern shopping mall", Journal of Marketing Management, Vol. 10, No. 1-3, pp. 163-78.

Hamermesh, D., and Lee, J. (2007), "Stressed out on four continents? Time crunch or yuppie kvetch"? The Review of Economics and Statistics, Vol. 89, No. 2, pp. 374-83.

Handy, S., and Clifton, K. (2001), "Local shopping as a strategy for reducing automobile travel", Transportation, Vol. 28, No. 4, pp. 317-46.

Houston, M., \& Nevin, J. (1980), "Retail shopping area image: structure and congruency between downtown areas and shopping centers", Advances in Consumer Research, Vol. 7, No. 1, pp 677-81.

Howell, R., \& Rogers, J. (1980), "Research into shopping mall choice behaviour", Advances in Consumer Research, Vol. 7, No. 1, pp 671-66.

Ibrahim, M., and Ng, W. (2002), "The importance of entertainment in the shopping center experience: Evidence from Singapore", Journal of Real Estate Portfolio Management, Vol. 8, No. 3, pp. 239-54. 
Joh, C-H., Arentze, T., and Timmermans, H. (2006), "Characterisation and comparison of gender-specific utility functions of shopping duration episodes", Journal of Retailing and Consumer Services, Vol. 13, No. 4, pp. 249-59.

Kaufman, C. (1996), "A new look at one stop shopping: a TIMES model approach to matching store hours and shopping schedules", Journal of Consumer Marketing, Vol. 13, No. 1, pp. 4-25.

Kaufman, C., and Lane, P. (1994), "Shopping 24 hours a day: A consumer need or a losing strategy", Journal of Shopping Center Research, Vol. 1, No. 1, pp. 81-159.

Kaufman-Scarborough, C., and Lindquist, J. (2003), "Understanding the experience of time scarcity", Time and Society, Vol. 12, No 2/3, pp. 349-70.

Kim, I., Christiansen, T., Feinberg, R., and Choi, H. (2005), "Mall entertainment and shopping behaviors: A graphical modeling approach", Advances in Consumer Research, Vol. 32, No. 1, pp. 487-92.

Kim, Y-K., and Kang, J. (1997), "Consumer perception of shopping costs and its relationship with retail trends", Journal of Shopping Center Research, Vol. 4, No. 2, pp. 27-.

Kim, H-Y., and Kim, Y-K. (2008), "Shopping enjoyment and store shopping modes: The moderating influence of chronic time pressure", Journal of Retailing and Consumer Services, Vol. 15, No. 5, pp 410-19.

Kim, Y-K., Sullivan, P., and Forney, J. (2007), Experiential Retailing: Concepts and strategies that sell, Fairchild Publications, New York.

LeHew, M.L.A., and Cushman, L. (1998), "Time-sensitive consumers' preference for concept clustering: An investigation of mall tenant placement strategy", Journal of Shopping Center Research, Vol. 5, No. 1, pp. 33-58.

Leo, P., and Philippe, J. (2002), "Retail centres: Location and Consumer's satisfaction", The Service Industries Journal, Vol. 22, No. 1, pp. 122-46.

Leszczyc, P., Sinha, A., and Sahgal, A. (2004), "The effect of multi-purpose shopping on pricing and location strategy for grocery stores", Journal of Retailing, Vol. 80, No. 2, pp. 85-99.

Lewison, D.M. (1997), Retailing, 6th edition, Prentice-Hall, USA.

Liebmann, W. (2000), "How America shops", Vital speeches of the day, Vol. 66, No. 24, pp. 753-57.

Loewenthal, K.M (2001), An introduction to psychological tests and scales, $2^{\text {nd }}$ edition, UCL Press, London.

Lorch, B., and Smith, M (1993), "Pedestrian movement and the downtown enclosed shopping center", Journal of the American Planning Association, Vol. 59, No. 1, pp. 7584. 
Malhotra, N., Hall, J., Shaw, M., and Crisp, M. (2002), Marketing Research: An applied orientation, $2^{\text {nd }}$ Edition, Prentice Hall, Sydney.

Mason, J.B., Mayer, M.L., and Wilkinson, J.B (1993), Modern Retailing: Theory and Practice, $6^{\text {th }}$ edition, Irwin, USA.

McGoldrick, P., and Thompson, M. (1992), "The role of image in the attraction of the outof-town centre", The International Review of Retail, Distribution, and Consumer Research, Vol. 2, No. 1, pp. 81-92.

Mitchell, V-W., and Walsh, G. (2004), "Gender differences in German consumer decision-making styles", Journal of Consumer Behavior, Vol. 3, No. 4, pp. 331-346.

Moss, M. (2007), Shopping as an entertainment experience, Lexington Books, New York.

Muto, S. (1994), Galleria: 26 shopping centers in Europe, Graphic-sha, Tokyo.

Neo, L., and Wing, T. (2005), The 4R's of Asian shopping centre management, Marshall Cavendish, Singapore.

New American Dream (2003), "Take back your time", available at: http://www.newdream.org/live/time/tbytd.php, (accessed May $14^{\text {th }} 2008$ ).

Northen, R., and Haskell, M. (1977), Shopping Centres, CALUS, College of Estate Management.

Pacelle, M. (1996), "The aging shopping mall must either adapt or die", The Wall Street Journal, April 16, pp. B1, B16.

Quee, W. (1999), Marketing Research, 3rd edition, Marketing Institute of Singapore, Melbourne.

Reimers, V., and Clulow, V. (2008A), "How do consumers define retail centre convenience?", submitted.

Reimers, V., and Clulow, V. (2008B), "Retail centre convenience: Its' influence over consumer patronage behaviour", submitted.

Richbell, S., and Kite, V. (2007), "Night shoppers in the "open 24 hours" supermarket: A profile", International Journal of Retail and Distribution Management, Vol. 35, No. 1, pp. 54-68.

Robertson, K. (1988), “Pedestrian skywalk systems: Downtown's great hope or pathways to ruin?", Transportation Quarterly, Vol. 42, No. 3, pp. 457-84.

Schultz, D.P. (1997), "Panelists stress high expectations for neighborhood, on-line retailing", Stores, Vol. 79, No. 3, pp. 321-322. 
Schwartz, J. (1992), "Climate controlled customers", American Demographics, Vo. 14, No. 3, pp. 24-32.

Smith, P. (1956), Shopping Centers: Planning and Management, The National Retail Merchants Association of New York, New York.

Stoltman, J., Morgan, F., and Anglin, L. (1999), "An investigation of retail shopping situations", International Journal of Retail and Distribution Management, Vol. 27, No. 4, pp. 145-53.

Sullivan, O., and Gershuny, J. (2004), "Inconspicuous consumption: Work-rich, time-poor in the liberal market economy", Journal of Consumer Culture, Vol. 4, No. 1, pp. 79-100.

Teller, C., and Reutterer, T. (2008), "The evolving concept of retail attractiveness: What makes retail agglomerations attractive when customers shop at them"? Journal of Retailing and Consumer Services, Vol. 15, No. 3, pp. 127-43.

Wajcman, J. (2008), "Life in the fast lane? Towards a sociology of technology and time", The British Journal of Sociology, Vol. 59, No. 1, pp. 59-77.

Yavas, U. (2003), "A multi-attribute approach to understanding shopper segments", International Journal of Retail and Distribution Management, Vol. 31, No. 11, pp. 541-48. 